\title{
EFFECT OF ABRASIVE WATERJET PEENING SURFACE TREATMENT OF STEEL PLATES ON THE STRENGTH OF SINGLE-LAP ADHESIVE JOINTS
}

\author{
Kamil Anasiewicz' ${ }^{1}$ Józef Kuczmaszewski ${ }^{1}$ \\ 1 Department of Production Engineering, Faculty of Mechanical Engineering, Lublin University of Technology, \\ 36 Nadbystrzycka St., 20-618 Lublin, Poland, e-mail: k.anasiewicz@pollub.pl, j.kuczmaszewski@pollub.pl
}

Received: 2017.05 .15 Accepted: 2017.08.01 Published: 2017.09.03

\begin{abstract}
The paper presents the results of a comparative study of shear strength of single-lap adhesive joints, depending on the method of surface preparation of steel plates with increased corrosion resistance. The method of preparing adherend surfaces is often one of the most important factors determining the strength of adhesive joints. Appropriate geometric surface development and cleaning of the surface enhances adhesion forces between adherend material and adhesive. One of the methods of shaping engineering materials is waterjet cutting, which in the AWJP - abrasive waterjet peening variant, serves to shape flat surfaces of the material by changing the roughness and introducing stresses into the surface layer. These changes are valuable when preparing adhesive joints. In the study, surface roughness parameters obtained with AWJP treatment, were analyzed in direct relation to the strength of the adhesive joint. As a consequence of the experimental results analysis, the increase in the strength of the adhesive joints was observed in a certain range of parameters used for AWJP treatment. A decrease in shear strength of adhesive joint with the most modified topography of overlap surface was observed.
\end{abstract}

Keywords: abrasive waterjet peening, AWJP, adhesive bonding, lap joints.

\section{INTRODUCTION}

In the technology of making adhesive joints there is a group of factors which determine the quality of the joint. These factors are divided into technological and design factors. Technological factors to be mentioned are: type of adhesive and method of its application, method of surface preparation of bonded elements, conditions of adhesive bonding. The most important design factors include the shape and dimensions of the joint and loading conditions $[4,8]$. Widespread use and development of adhesive bonding technology involves continuous search for new solutions to improve the bonding process and increase strength of bonding. As it has been shown in many studies, the method of surface preparation and degree of its geometric surface development has a signifi- cant effect on strength of the adhesive joint $[3,4$, $7,8]$. Adequate preparation of the bonding surface guarantees an increase in adhesion forces, which are responsible for the adherence of the adhesive to the adherend material [6].

Shaping parts geometry with waterjet has recently gained a lot of popularity due to many advantages associated with this process. Abrasive waterjet cutting gives the possibility to process a variety of materials, often with a relatively high thickness and high hardness, it provides increased cutting precision, allowing to avoid additional machining and ensures optimum material use. Waterjet cutting allows for reduction or complete elimination of the heat-affected zone during operation. Despite many advantages of waterjet cutting, this technique is also characterized by some drawbacks, including: possibility to cut 
only through the entire thickness of the element, adverse working conditions for certain materials and the use of waterjet cutting only for flat surfaces [9]. The last of the limitations of the water-jet cutting process found other application, associated with the ability to shape the geometric structure of the element, as well as the specific features of the surface layer as a hydroabrasive effect of surface peening. This process, presented in the literature as AWJP - abrasive waterjet peening, is a machining method which utilizes controlled hydrodynamic erosion, whereby the topography of the surface can be changed to give it the desired roughness, with a high degree of purification. Simultaneously with the change of topography, the hardened top layer of the material is obtained by introducing residual compression stresses [1].

Hydroabrasive peening AWJP can be treated as a combination of water jet cutting and shot blasting. The AWJP process involves the use of a high pressure water jet provided with abrasive, i.e. directed to the target material surface in the direction of the jet impact. The high-pressure pump, which supplies pressure in the range of 40-600 $\mathrm{MPa}$, produces a stream that serves as a conveying medium for abrasives. In comparison to the waterjet cutting, a relatively large distance between the nozzle and the worpiece is used to expand the jet stream before impact and increase the machining of the surface area [9]. An AWJP machining scheme with indicated important elements is shown in Figure 1.
Abrasive waterjet peening (AWJP) can be used as a surface treatment process of metal orthopedic implants. AWJP treatment improves the ability of the implant to stabilize in a consequence of geometric surface texture development, which directly affects the increase of the level of osseointegration, while improving the fatigue strength of the element [1]. The AWJP treatment process, due to the advantages associated with it, can be used in the preparation of surface for adhesive bonding.

\section{EXPERIMENTAL DETAILS}

Comparative studies of single-lap adhesive joints of corrosion resistant steel plates X5CrNi18-10 (acc. to PN-EN 10088-1: 2007) were performed. Four series of samples were prepared, 5 each (Fig. 2). Surface samples in series No. 2, 3 and 4 were prepared by hydroabrasive peening treatment with variable parameters. The surface was prepared by performing two parallel passes with a width greater than the size of the overlap and then standardized size of samples were cut out. Hydroabrasive surface preparation and samples cutting were performed on the Eckert Opal Waterjet Combo thermal and waterjet cutter. For comparison purposes, samples with grinded surface were prepared. Surfaces of series No. 1 samples before bonding were grinded with 320 grit abrasive cloth. Then, the surface of all samples was degreased with Loctite 7063 degreasing agent. The joint was made at an am-

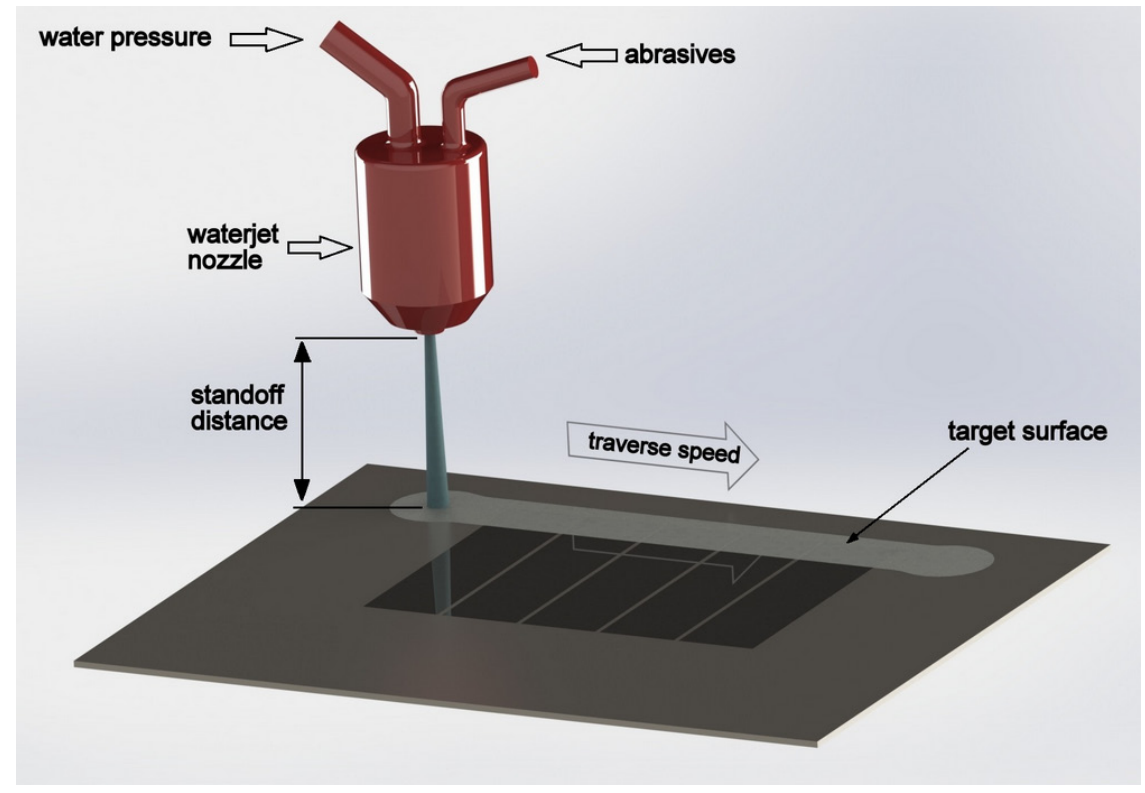

Fig. 1. Schematic drawing of AWJP surface treatment 


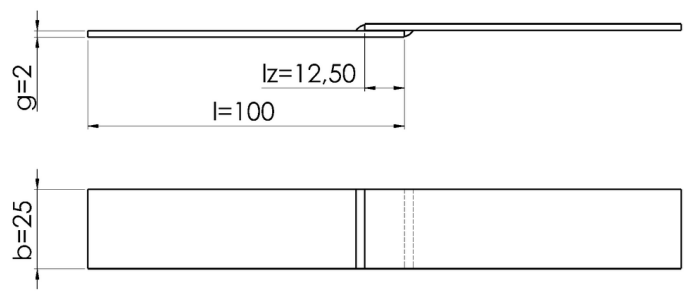

Fig. 2. Schematic drawing of examined single-lap adhesive joint

bient temperature of $18 \div 20{ }^{\circ} \mathrm{C}$ and relative humidity of $38 \div 40 \%$. The $\mathrm{E} 57$ epoxy resin was onestage cured with PAC curing agent, at room temperature for 7 days, with the use of uniform load on lap surface of all samples. Applied load was about $0.1 \mathrm{MPa}$. When the joint was completely cured, the spew fillet was removed to maintain defined surface area of the lap. Tensile strength tests were carried out on the Zwick / Roell Z150 tensile and compression testing machine, according to PN-EN 1465:2009 standard.

Elements were bonded with epoxy adhesive Epidian 57/PAC (E57 epoxy resin cured with polyaminoamide (PAC)) at a mass ratio of 10:7. The surface preparation parameters along with the exemplary overlap surface are shown in Table 1.

Table 2. shows the spatial parameters of surface roughness measured at length of $4.8 \mathrm{~mm}$ and width of $4.8 \mathrm{~mm}$, along with parameters of the selected roughness profile. The measurement was carried out parallel to the traces formed in the feed direction of the waterjet nozzle.

\section{TEST RESULTS AND DISCUSSION}

The shear strength results of tensile tested single-lap adhesive joint in relation to the spatial average roughness parameter $\mathrm{Sa}$ is shown in Figure 3.

Table 1. Surfaces of the overlap area and parameters of the treatment

\begin{tabular}{|c|c|c|c|c|}
\hline Series No. & 1 & 2 & 3 & 4 \\
\hline $\begin{array}{l}\text { Overlap sur- } \\
\text { face }\end{array}$ & $0 \mathrm{~mm} \quad 10 \mathrm{~mm}$ & $0 \mathrm{~mm} \quad 10 \mathrm{~mm}$ & $0 \mathrm{~mm} \quad 10 \mathrm{~mm}$ & omm \\
\hline Machining type & Grinding & $\begin{array}{c}\text { Abrasive waterjet peen- } \\
\text { ing }\end{array}$ & $\begin{array}{c}\text { Abrasive waterjet peen- } \\
\text { ing }\end{array}$ & $\begin{array}{c}\text { Abrasive waterjet peen- } \\
\text { ing }\end{array}$ \\
\hline $\begin{array}{c}\text { Variable } \\
\text { parameters }\end{array}$ & - & Pressure - $50 \mathrm{MPa}$ & Pressure - $150 \mathrm{MPa}$ & Pressure - $250 \mathrm{MPa}$ \\
\hline $\begin{array}{l}\text { Constant pa- } \\
\text { rameters }\end{array}$ & $\begin{array}{l}\text { Abrasive cloth } 320 \text { grit, } \\
\text { time } 2 \text { minutes }\end{array}$ & \multicolumn{3}{|c|}{$\begin{array}{c}\text { Feed rate } \mathrm{f}=2500 \mathrm{~mm} / \mathrm{min} \\
150 \mathrm{~mm} \text { nozzle distance } \\
\text { Abrasive Mesh } 80 \mathrm{D} \text { Super Garnet } \\
\text { Abrasive expense } 70 \%\end{array}$} \\
\hline
\end{tabular}

Table 2. Spatial parameters of surface roughness and parameters for selected roughness profile of series 1-4

\begin{tabular}{|c|c|c|c|c|c|}
\hline \multicolumn{6}{|c|}{ Spatial parameters of surface roughness } \\
\hline Series No. & $\mathrm{Sa}[\mu \mathrm{m}]$ & Sz $[\mu \mathrm{m}]$ & $\mathrm{Sp}[\mu \mathrm{m}]$ & Sv $[\mu \mathrm{m}]$ & $\mathrm{Sq}[\mu \mathrm{m}]$ \\
\hline 1 & 0,2 & 4,8 & 2,2 & 2,6 & 0,27 \\
\hline 2 & 1,6 & 25,1 & 11,8 & 13,3 & 2,1 \\
\hline 3 & 7,9 & 93,2 & 49,1 & 44,1 & 10 \\
\hline 4 & 11,7 & 131 & 60,7 & 70,3 & 14,8 \\
\hline \multicolumn{6}{|c|}{ Parameters of roughness profile } \\
\hline Series No. & $\mathrm{Ra}[\mu \mathrm{m}]$ & $\mathrm{Rz}[\mu \mathrm{m}]$ & & $\mathbf{R t}[\mu \mathrm{m}]$ & $\mathrm{Rp}[\mu \mathrm{m}]$ \\
\hline 1 & 0,2 & 1,4 & & 1,8 & 0,6 \\
\hline 2 & 1,5 & 9,8 & & 11,9 & 4,5 \\
\hline 3 & 8,1 & 45,9 & & 60,8 & 20,6 \\
\hline 4 & 9,3 & 41,2 & & 52,8 & 20,2 \\
\hline
\end{tabular}




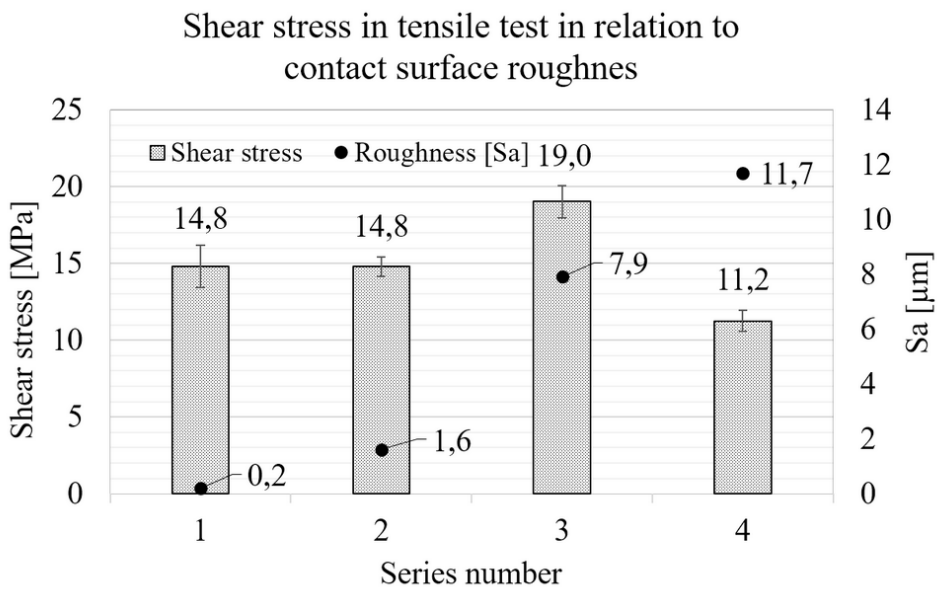

Fig. 3. Shear strength of tensile tested single-lap adhesive joint compared with the spatial arithmetical mean height roughness parameter $\mathrm{Sa}$ for the series 1-4

In the analysis of the research results, there was no significant change in the shear strength of the single-lap adhesive joint of series No. 2 prepared by the AWJP method, for which an arithmetical mean height roughness parameter $\mathrm{Sa}$ of $1,6 \mu \mathrm{m}$ was achieved compared to the series No. 1 samples, prepared by grinding with abrasive cloth $(\mathrm{Sa}=0,2 \mu \mathrm{m})$. Despite the lack of unequivocal change in shear strength of the single-lap joint, increased results were repeatability observed. Significant increase of single-lap adhesive joint shear strength was observed for a series No. 3 samples, with surface prepared by the AWJP method (150 MPa), which is characterized by roughness parameter $\mathrm{Sa}=7,9 \mu \mathrm{m}$. The increase in strength of the adhesive joint can be explained by the increase in adhesion of the adhesive to the adherend contact surface, due to the geometric surface development and the increase in the actual wetting surface. Surface purification and increased surface energy directly influenced the increase of shear strength of the lap adhesive joint while reducing the standard deviation. The increase in joint strength for series No. 3 was $28.6 \%$, compared to the reference series No. 1 . The results of the shear strength tests carried out on the series No. 4, processed with the AWJP $(250 \mathrm{MPa})$, with surface described by the spatial parameter $\mathrm{Sa}=11,7 \mu \mathrm{m}$, reveal lack of continuation in trend of shear strength growth along with the increase in the Sa roughness parameter. There was a significant reduction in the shear strength of the single-lap joint of series No. 4. The drop in reference to series No. 1 was $24,1 \%$ and to the series No. $3-41 \%$. The lower shear strength of the joint may be due to the insufficient filling of the contact surface of the bonded component, as an outcome of hydroabrasive peening, which results in a reduction in mechanical adhesion. A summary of rupture strength and shear tensile strength for series $1-4$ is presented in Table 3 .

Fig. 4 shows a graphic representation of topography of prepared overlap surface. 3D surface topography maps were obtained using a contour, roughness and topography $3 \mathrm{D}$ machine $\mathrm{T} 8000$ RC120-400 Hommel - Etamic.

Table 3. Rupture strength values and shear tensile strength of series 1-4

\begin{tabular}{|c|c|c|c|c|}
\hline Series No. & $\mathbf{1}$ & $\mathbf{2}$ & $\mathbf{3}$ & $\mathbf{4}$ \\
\hline Rupture strength [MPa] & 14,3 & 14,4 & 18,2 & 8,5 \\
\hline Standard deviation [MPa] & 2,6 & 1,4 & 2 & 1,4 \\
\hline Coefficient of variation [\%] & 18,1 & 9,4 & 10,7 & 16,2 \\
\hline Series No. & 1 & 2 & 3 & 4 \\
\hline Shear tensile strength [MPa] & 14,8 & 14,8 & 19 & 11,2 \\
\hline Standard deviation [MPa] & 2,7 & 1,3 & 2,1 & 1,4 \\
\hline Coefficient of variation [\%] & 18,3 & 8,6 & 11 & 12,3 \\
\hline
\end{tabular}



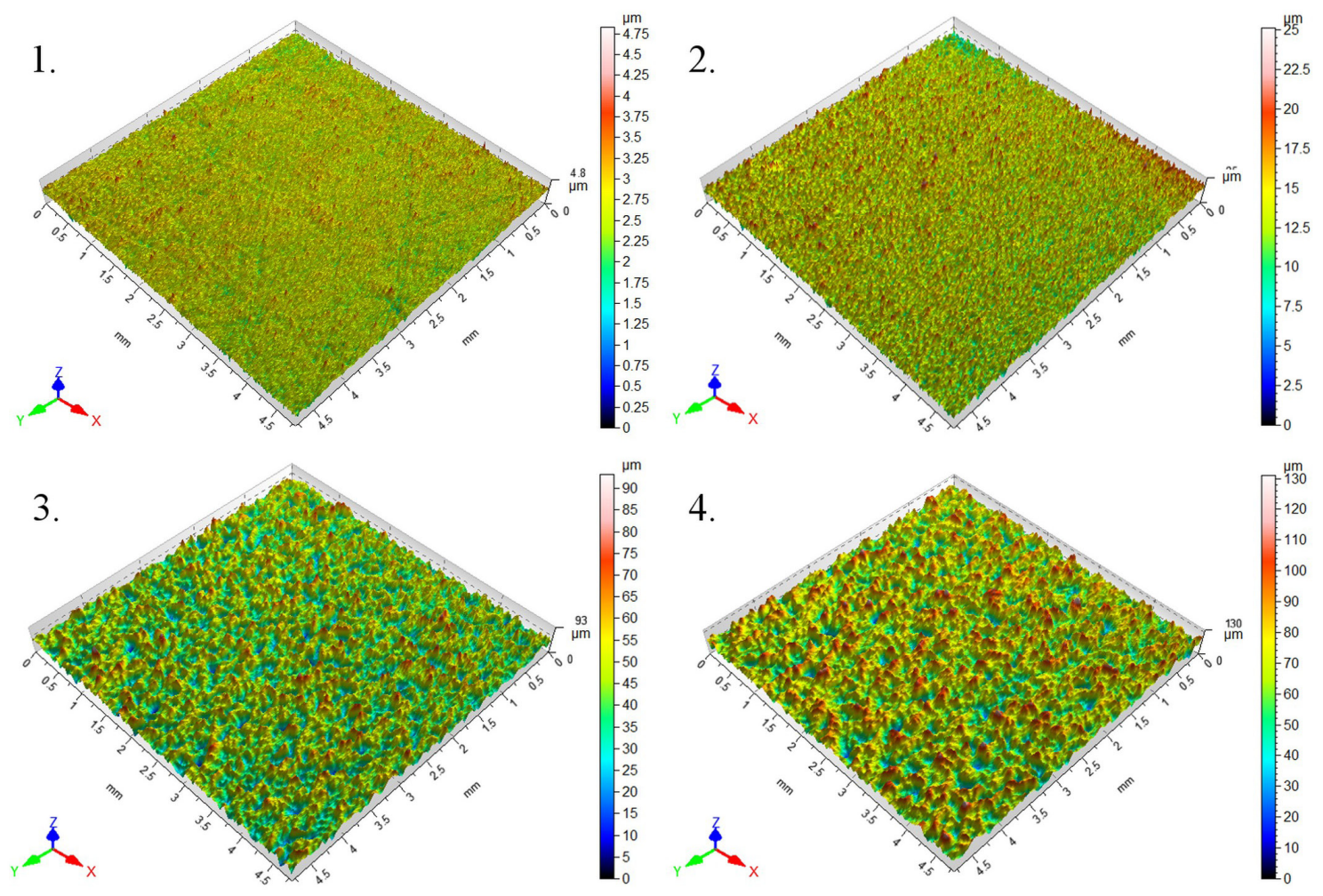

Fig. 4. Sample 3D topography of the overlap surface for 1-4 series

On the 3D surface topography map of series No. 4 a significant difference in the maximum surface roughness can be observed. Parameter of the maximum height of the surface $\mathrm{Sz}$ - the difference between the lowest valley and the highest peak, reaches $\mathrm{Sz}=131 \mu \mathrm{m}$ for series No. 4, compared to $\mathrm{Sz}=93,2 \mu \mathrm{m}$ for series No. 3. Significant difference in the value of this parameter may affect the surface fill efficiency with adhesive in the bounding area, especially in the case of the adherend sheet, which constituted the upper part of the joint at the time of adhesive curing.

The increase in waterjet pressure, in hydroabrasive treatment, particularly influences the increase of the maximum value of the surface height $\mathrm{Sz}$, with simultaneous slight increase of the remaining roughness parameters. Such high roughness parameters have a highly relevant effect on adhesion [5]. The value of these parameters is a direct consequence of the removal of the material particles from the substrate and its local strain hardening, which may have the effect of strengthening the material in the lap area. Due to the dynamic nature of abrasive waterjet peening it is possible to increase the residual compressive stresses in the top layer at a greater depth than in the case of static peening [2]. Fig. 5 shows selected surface roughness profiles for series No. 1-4.

Fig. 6 shows a graph of stress - elongation curve of the exemplary single-lap adhesive joint of series No. 4. The graph shape indicates a similarity to the tension curves obtained with tension tests of dumbbell-shaped samples of epoxy materials according to PN-EN ISO 527-4:2000. A very clear point of maximum shear stress and progressive plastic deformation can be observed until a rupture stress is attained. Such a clear plastic deformation of the adhesive was not present in the other tested samples. The shape of the graph may suggest that the adhesive joint of the series No. 4 samples was characterized by a higher effective thickness compared to the other samples, which was conducive to observing the plastic deformation of the adhesive joint.

The observed plastic deformation can be attributed to the core deformation of the bonding, which indicates greater thickness of adhesivebonded joint in the series No. 4. sample. The increased amount of adhesive in the contact area can be observed in Fig. 7, showing the failure surfaces of the samples.

The failure surface of series No. 1 and 2 samples, show typical signs of combined adhe- 

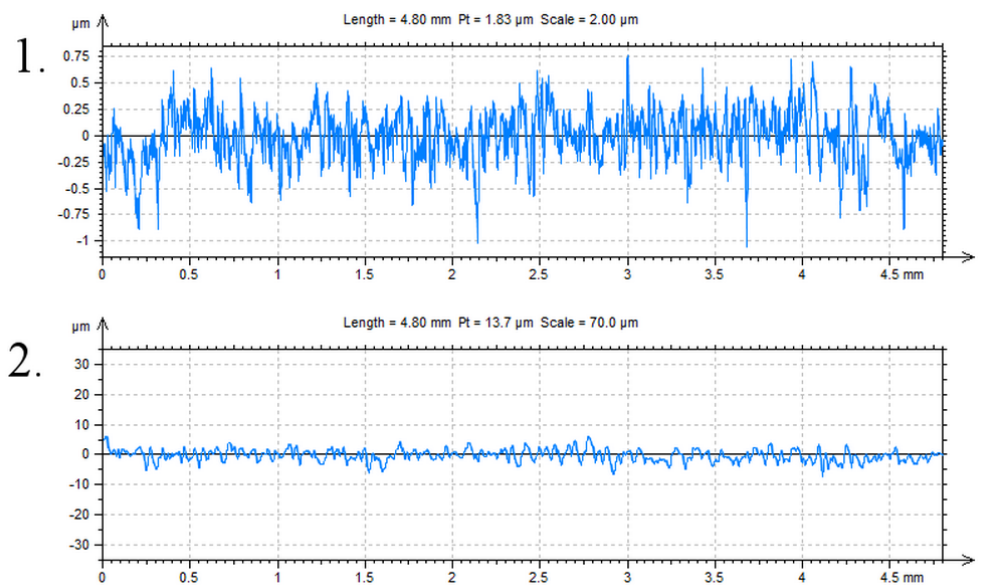

3.

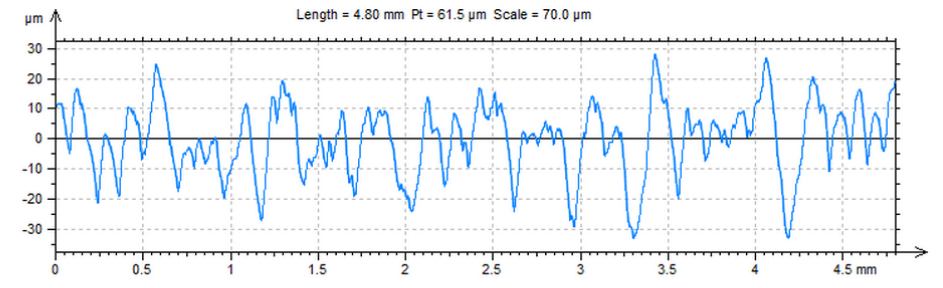

4.

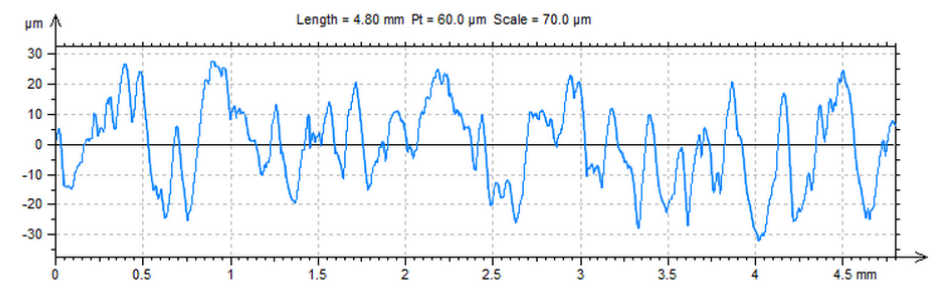

Fig. 5. Surface roughness profiles of samples of 1-4 series

sion-cohesion failure with adhesion type predominance. In the case of series No. 3, noticeable adhesion-cohesion failure with cohesive failure superiority can be recognized. On the failure surface of the sample No. 4 mainly cohe-

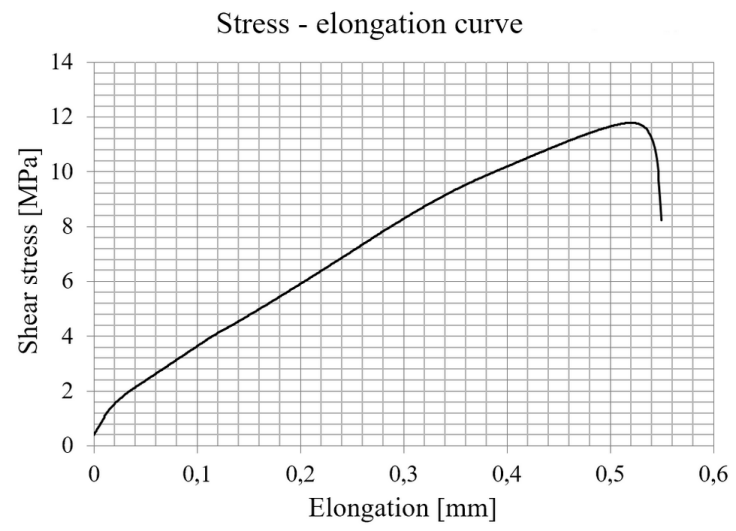

Fig. 6. Graph of strain - elongation curve for the sample of series No. 4
1.

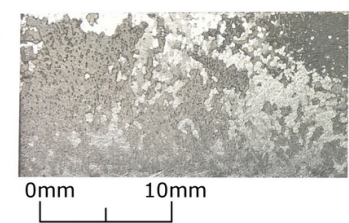

2.
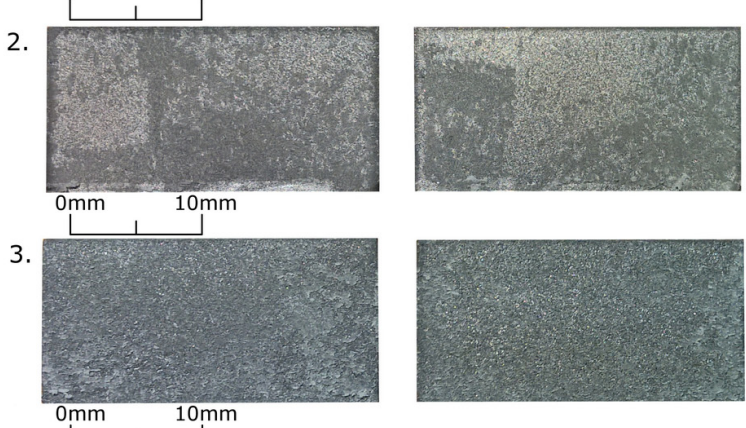

4.
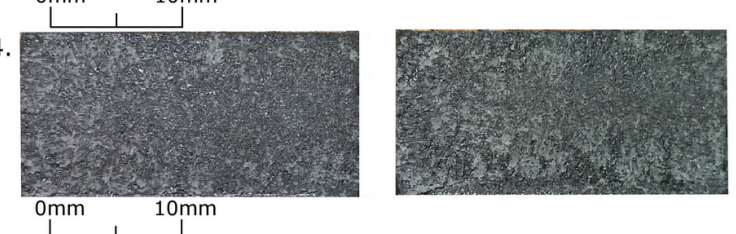

Fig. 7. Exemplary failure surfaces of overlap samples of series $1-4$ 
sive failure can be observed, which would indicate a significant increase in adhesion forces responsible for adhesive adhesion to the adherend material. Increased amount of adhesive layer in the bounding area was observed compared to other samples.

\section{CONCLUSIONS}

The analysis of the results of the experimental research allows to formulate the following important conclusions:

- The use of the AWJP method for shaping the adhesive properties of the top layer of construction materials can yield the desired effects of increasing the strength of singlelap adhesive joints for a certain range of process parameters.

- Decrease in the shear strength of the singlelap adhesive joint, surface properties for the highest roughness parameter $\mathrm{Sa}(11.7 \mu \mathrm{m})$ was observed. The reduction in strength could have occurred as a result of the limited adhesive penetration into the micropores of the adherend surface, which reduced the actual wetting surface.

- AWJP treatment allows to obtain the desired level of geometric surface development, depending on the parameters used, at a high repeatability degree. Parameters can be precisely controlled due to the integrated numerical control of the machine, which drives 3 axes with highly precise guides on linear bearings.

- It can be concluded that the decrease in strength for the series of samples No. 4 is related to the viscosity of the adhesive, thus also its ability to fill pits. Possibly, reduction in viscosity would cause a relative increase of adhesive joint strength for considered topography of the surface.

- Despite the observed improvement in shear strength of the single-lap adhesive joints, in a certain range of parameters, AWJP surface preparation is associated with corrosion-related disadvantages due to the adverse effect of water on the workpiece. In addition, in the case of waterjet abrasive peening surface treatment, an additional allowance shall be provided for the engage and retract of the waterjet nozzle. Surface in traverse area is characterized by dif- ferent roughness parameters, in comparison to the proper surface of the pass.

- Identification of the boundary value of the roughness parameters $\mathrm{Sa}$ and $\mathrm{Sz}$, which may be directly related to the observed decrease in shear strength of the adhesive joint, requires more detailed research in the field of roughness parameters changes of the prepared overlap surface.

In conclusion, the results obtained are encouraging and may, under certain conditions, constitute a significant complement to the technology used to shape the adhesive properties of the surface of construction materials.

\section{REFERENCES}

1. Arola D. D., McCain M. L. Abrasive Waterjet Peening: A New Method of Surface Preparation for Metal Orthopedic Implants. John Wiley \& Sons, Inc. J Biomed Mater Res (Appl Biomater), 53, 536-546.

2. Bławucki S., Zaleski K. Nagniatanie dynamiczne kompozytów o osnowie metalowej. Mechanik, 3, 2015, 163-167.

3. Budhe S., Ghumatkar A., Birajdar N., Banea M. D. Effect of surface roughness using different adherend materials on the adhesive bond strength. Applied Adhesion Science, 2015.

4. Fernando D., Teng J. G., Yu T., Zhao X. L., Preparation and Characterization of Steel Surfaces for Adhesive Bonding. Journal of Composites for Construction, 6(17), 2013, 1-10

5. Grzesik W. Wpływ topografii powierzchni na właściwości eksploatacyjne części maszyn. Mechanik, 8-9, 2015, 587-593.

6. Kuczmaszewski J. Podstawy konstrukcyjne i technologiczne oceny wytrzymałości adhezyjnych połączeń metali. Wydawnictwa Uczelniane Politechniki Lubelskiej, 1995.

7. Müller M. Influence of surface integrity on bonding process. Research in Agricultural Engineering, 4(57), 2011, 153-162.

8. Rudawska A. Wpływ sposobu przygotowania powierzchni na wytrzymałość połączeń klejowych blach ze stali odpornej na korozję. Technologia i Automatyzacja Montażu 3, 2010, 36-39.

9. Sreekesh. K, Govindan P. A review on abrasive water jet cutting. International Journal of Recent Advances in Mechanical Engineering, 3(3), 2014, 153-158. 